\title{
IMPACT OF TEMPERATURE ON BIOLOGICAL DENITRIFICATION PROCESS
}

\author{
Er. Iswar Man Amatya \\ Associate. Prof. Pulchowk Campus, Institute of Engineering, Tribhuvan University \\ Er. Bhagwan Ratna Kansakar, Ph.D. \\ Prof. Pulchowk Campus, Institute of Engineering, Tribhuvan University \\ Er. Vinod Tare, Ph.D. \\ Prof. Indian Institute of Technology, Kanpur,
}

Liv Fiksdal, Ph.D.

Prof. NTNU, Norway

\begin{abstract}
Nitrate removal in groundwater was carried out by biological method of denitrification process. The denitrification and without denitrification were performed in two different sets of reactors. Each reactor consists of two columns connected in series packed with over burnt bricks as media. The filtration rate varied from 5.3 to $52.6 \mathrm{~m} /$ day for denitrification process. The ammonia, nitrate and nitrite nitrogen concentrations were measured at inlet, intermediate ports and outlet. The temperature varied from 10 to $30^{\circ} \mathrm{C}$ at $2^{\circ} \mathrm{C}$ intervals. The results demonstrated that high amount of nitrate nitrogen removed in groundwater at denitrification process. The nitrate nitrogen removed by denitrification varied from 3.50 to $39.08 \mathrm{gm} / \mathrm{m}^{3} / \mathrm{h}$ at influent concentration from 6.32 to $111.04 \mathrm{gm} / \mathrm{m}^{3} / \mathrm{h}$. Denitrification was found more significant above $16^{\circ} \mathrm{C}$.
\end{abstract}

Key words: Over burnt brick, Denitrification, Filtration rate and Temperature

\section{INTRODUCTION}

The major concern affecting human health pertains to infants less than six months of age. In sufficient quantities, at nitrate concentrations exceeding $10 \mathrm{mg} / \mathrm{l}$, the possibility of health hazard is significant towards infants. The primary health hazard from drinking water with nitrate- $\mathrm{N}$ occurs when nitrate is transformed to nitrite in the digestive system due to ammonia present in source water. The nitrite oxidizes iron in the hemoglobin of the red blood cells to form methemoglobin, which lacks the oxygen carrying ability of hemoglobin. This creates the condition known as methemoglobinemia. This is also known as blue baby syndrome causing the veins and skins to appear blue. There has been some potential link between high nitrates in drinking water and gastrointestinal cancer. Higher nitrates concentration of $100 \mathrm{mg} / \mathrm{l}$ in drinking water has been associated with adult cancer of stomach and bladder.

To minimize the foreign chlorine materials as coagulants in nitrate treatment and to reduce the negative effect of nitrite / nitrate in human bodies, to reduce the toxic effects of chlorinated effluent discharge, feasible scale in actual application for higher concentration, biological growth (denitrification) process is one of the option of removing the nitrate from water. This process does not produce harmful toxic byproducts and is beloved to be eco-friendly.

However, this is especially important when and denitrification process [1] is of concern. 
Denitrification is the biochemical reduction of nitrates, under saturate conditions, to $\mathrm{N}$ gases, $\mathrm{N}_{2}$ or $\mathrm{N}_{2} 0$, and accounts for approximately 80 percent of the $\mathrm{N}$ lost. Nitrate $\mathrm{N}$ is the only form of $\mathrm{N}$, which is of major importance in $\mathrm{N}$ loss. The autotrophic denitrification process requires inorganic carbon as food or energy source. However, inorganic carbon, i.e., bicarbonate/carbonate, must be provided as food source. In addition, a suitable electron acceptor must also be provided. Although autotrophic denitrifying bacteria function well in anaerobic conditions, in many cases autotrophic mode of denitrification have been shown by facultative organisms i.e. Paracoccus denitrificants, Thiobacillus denitrificants, etc. [2]. Denitrification kinetics were investigated in water systems at various temperatures.

One of the major factors affecting denitrification in treatment is temperature. Low temperatures have generally a drastic effect on bacterial process rates, a phenomenon characteristic of all biochemical systems. However, this is especially important when denitrification processes [1] are of concern. Denitrification is considered to be a surface-based process in water and wastewater systems [3]. It has been widely used for denitrifying nitrate to nitrite and nitrogen gas.

Guideline values for chemicals Nonpesticides Nitrate (as $\mathrm{NO}_{3}^{-}$) and Nitrite (as $\mathrm{NO}_{2}{ }^{-}$) from agricultural activities are of 50 $\mathrm{mg} /$ liter and $3 \mathrm{mg} / \mathrm{liter}$ of health significance in drinking water at short-term exposure [4].

The major concern affecting human health pertains to infants less than six months of age. In sufficient quantities, at nitrate concentrations exceeding $10 \mathrm{mg} / \mathrm{l}$., the possibility of health hazard is significant towards infants. The primary health hazard from drinking water with nitrate- $\mathrm{N}$ occurs when nitrate is transformed to nitrite in the digestive system due to ammonia present in source water.

The nitrite oxidizes iron in the hemoglobin of the red blood cells to form methemoglobin, which lacks the oxygen carrying ability of hemoglobin. This creates the condition known as methemoglobinemia. This is also known as blue baby syndrome causing the veins and skins to appear blue. There has been some potential link between high nitrates in drinking water and gastrointestinal cancer. Higher nitrates concentration of $100 \mathrm{mg} / \mathrm{l}$ in drinking water has been associated with adult cancer of stomach and bladder.

Denitrification is the biochemical reduction of nitrates, under saturate conditions, to $\mathrm{N}$ gases, $\mathrm{N}_{2}$ or $\mathrm{N}_{2} 0$, and accounts for approximately 80 percent of the $\mathrm{N}$ lost. Nitrate $\mathrm{N}$ is the only form of $\mathrm{N}$, which is of major importance in $\mathrm{N}$ loss. The autotrophic denitrification process requires inorganic carbon as food or energy source. However, inorganic carbon, i.e., bicarbonate/carbonate, must be provided as food source. In addition, a suitable electron acceptor must also be provided. Although autotrophic denitrifying bacteria function well in anaerobic conditions, in many cases autotrophic mode of denitrification have been shown by facultative organisms i.e. Paracoccus denitrificants, Thiobacillus denitrificants, etc. [2]. Denitrification kinetics were investigated in water systems at various temperatures.

\section{Theoretical consideration}

The reduction of nitrate (and/or nitrite) into nitrogen gas or ammonia is termed as denitrification. In denitrification, anaerobic microbes strip away the chemically bound oxygen from the nitrite and nitrate, thus by liberates the nitrogen as nitrogen gas into the atmosphere. The ammonia conversion flow to nitrogen gas is presented in Figure 1. 


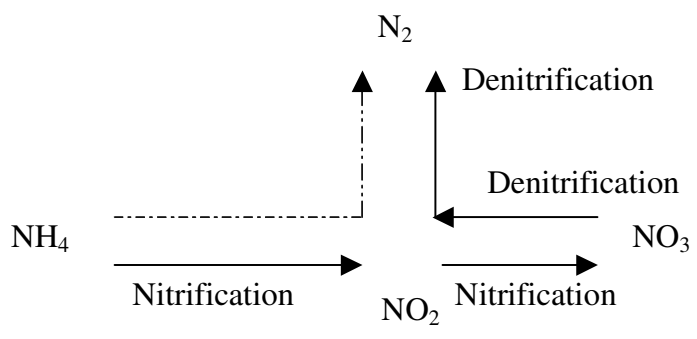

Figure 1 Ammonia Oxidation and Reduction Flow

Denitrification: autotrophic denitrification is the biochemical reduction of nitrates, under saturate conditions, to $\mathrm{N}$ gases, $\mathrm{N}_{2}$ or $\mathrm{N}_{2} 0$, and accounts for approximately 80 percent of the $\mathrm{N}$ lost. Nitrate $\mathrm{N}$ is the only form of $\mathrm{N}$, which is of major importance in $\mathrm{N}$ loss.

The autotrophic denitrification process requires inorganic carbon as food or energy source. However, inorganic carbon, i.e., bicarbonate/carbonate, must be provided as food source. In addition, a suitable electron acceptor must also be provided. Although autotrophic denitrifying bacteria function well in anaerobic conditions, in many cases autotrophic mode of denitrification have been shown by facultative organisms i.e. Paracoccus denitrificants, Thiobacillus denitrificants, etc. [5].

Autotrophic organisms use inorganic carbon as food source, and electron donors like hydrogen or reduced sulfur-compounds as energy source to reduce nitrate to nitrogen gas. Equations for autotrophic denitrification using hydrogen, thiosulfate and sulfide as electron donors are given as equations (1), (2) and (3) below [2].

Hydrogen:

$$
2 \mathrm{NO}_{3}^{-}+5 \mathrm{H}_{2} \rightarrow \mathrm{N}_{2}+4 \mathrm{H}_{2} \mathrm{O}+2 \mathrm{OH}^{-}
$$$$
\text { Eq. (1) }
$$

Thiosulfate:

$$
5 \mathrm{~S}_{2} \mathrm{O}_{3}^{2-}+8 \mathrm{NO}_{3}^{-}+\mathrm{H}_{2} \mathrm{O} \rightarrow 4 \mathrm{~N}_{2}+10 \mathrm{SO}_{4}^{2-}+2 \mathrm{H}^{+}
$$

Sulfide:

$$
\begin{gathered}
5 \mathrm{~S}^{2-}+8 \mathrm{NO}_{3}^{-}+8 \mathrm{H}^{+} \rightarrow 4 \mathrm{~N}_{2}+5 \mathrm{SO}_{4}^{2-}+4 \mathrm{H}_{2} \mathrm{O} \\
\ldots \ldots \ldots \text { Eq. (3) }
\end{gathered}
$$

As per theoretical calculations, stoichiometrically, $0.35 \mathrm{mg} / \mathrm{L}$ of $\mathrm{H}_{2}$ is required for complete denitrification of 1.0 $\mathrm{mg} / \mathrm{L} \mathrm{NO}_{3}-\mathrm{N}$. Provision of this hydrogen is costly and difficult. The autotrophic denitrification process is most effective when the $\mathrm{pH}$ is maintained near neutral. [2].

Under the circumstances it is conceivable that corrosion of $\mathrm{Fe}(0)$ in anaerobic environments may supply hydrogen that is required for autotrophic denitrification of nitrate as per Eq. (1), resulting in a combined reaction as described by Eq. (4) [5].

Biological Nitrate Reduction:

$$
\begin{gathered}
5 \mathrm{Fe}(0)+2 \mathrm{NO}_{3}^{-}+6 \mathrm{H}_{2} \mathrm{O} \rightarrow 5 \mathrm{Fe}^{2+}+\mathrm{N}_{2}+12 \mathrm{OH}^{-} \\
\ldots \ldots \ldots . . . \text {.... (4) }
\end{gathered}
$$

\section{MATERIALS AND METHODS}

\section{Experimental setup}

The reactors were constructed by using two high-density polythene (HDP) pipe columns in series of $132 \mathrm{~mm}$ internal diameter and $3 \mathrm{~m}$ height for both nitrification reactors. Two meters of filter media was used in each column with total depth of four meters. The six numbers of sampling ports were provided at $1 \mathrm{~m}$ interval in each set of reactors. The schematic flow diagram of experimental setup is presented in Figure 2. 


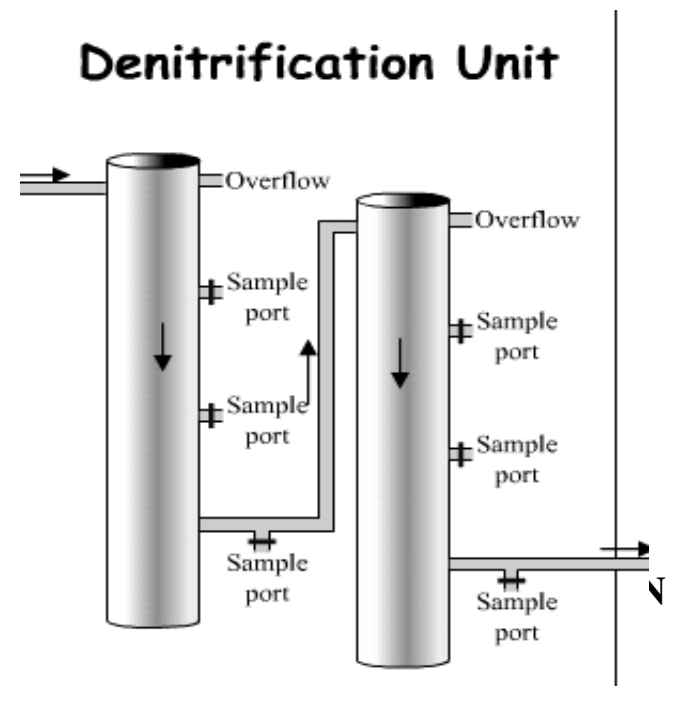

The media was selected by considering the physical, chemical and biological parameters of the raw water. The media sizes of 10 to $15 \mathrm{~mm}$ were packed in the columns. A perforated HDP sheet was used for supporting media in each column. The over burnt bricks (OBBs) was chosen as the media since it has shown the significant denitrification in the preliminary test. The media OBBs were first moistened and gently placed into column from top of the columns. The columns were slightly agitated to achieve a stable pack and eliminate unwanted voids. The characteristics of OBBs which were used as filter media are presented in Table 1.

Table 1: Characteristics of OBBs

\begin{tabular}{clcc}
\hline S.N. & Characteristics & Unit & Concentration \\
\hline 1 & Density dry & $\mathrm{gm} / \mathrm{cm}^{3}$ & $0.651 \sim 0.676$ \\
2 & Density wet & $\mathrm{gm} / \mathrm{cm}^{3}$ & $0.740 \sim 0.769$ \\
3 & Specific gravity & & $0.650 \sim 0.680$ \\
4 & Porosity & Percent & $43.7 \sim 45.1$ \\
5 & $\mathrm{pH}$ & & $6.67 \sim 6.71$ \\
6 & Void ratio & & $0.776 \sim 0.810$ \\
7 & Coefficient of & & $1.30 \sim 1.33$ \\
8 & uniformity $\left(\mathrm{C}_{\mathrm{u}}\right)$ & & 0.13 \\
9 & Iron & $\mathrm{mg} / \mathrm{l}$ & $\mathrm{ND}$ \\
10 & Phosphates & $\mathrm{mg} / 1$ & 0.25 \\
11 & Calcium & $\mathrm{mg} / 1$ & 3.11
\end{tabular}

$\begin{array}{llll}12 & \text { Chlorides } & \mathrm{mg} / \mathrm{l} & 1.42 \\ 13 & \text { Sodium } & \mathrm{mg} / \mathrm{l} & 0.16 \\ 14 & \text { Copper } & \mathrm{mg} / \mathrm{l} & \mathrm{ND} \\ 15 & \text { Silica } & \mathrm{mg} / \mathrm{l} & 4.38 \\ 16 & \text { Cadmium } & \mathrm{mg} / \mathrm{l} & \mathrm{ND} \\ 17 & \text { Arsenic } & \mathrm{mg} / \mathrm{l} & \mathrm{ND}\end{array}$

\section{REACTOR STARTUP AND OPERATION}

The media OBBs were fully exhausted first with nitrate water in reactors so as not to take intrusion by adsorption phenomena in denitrification column. The seed denitrifying culture was originally obtained from the experimental scale activated sludge plant that has been successfully performing denitrification. The inoculants thus prepared was poured into the submerged filters, retained for 1 week in denitrifying column. After this, the start-up time was considered complete and experiment was started.

The denitrification has been carried out in down flow submerged granular OBBs media. For denitrification, the filtration rate varied from 5.3 to $52.6 \mathrm{~m} /$ day. The influent nitrate nitrogen concentration varies from 110 to $280 \mathrm{mg} / \mathrm{l}$. Deoxygenating tank was used to reduce dissolved oxygen (DO) and supplying hydrogen for denitrification process. DO was maintained always less than $1.0 \mathrm{mg} / \mathrm{l}$ at all the times in denitrification reactor.

\section{RESULT AND DISCUSSION}

\section{Flow rate}

A set of autotrophic denitrification reactor with the OBBs as the media was used for the study. The water flowed in plug flow characteristics in the reactors. The study was made at temperatures which varied from $10^{\circ}$ $\mathrm{C}$ to $30^{\circ} \mathrm{C}$ at $2^{\circ} \mathrm{C}$ intervals, and was operated at flow rates of 5.3, 10.5, 15.8, 26.3, 42.1 and $52.6 \mathrm{~m} /$ day $(50,100,150,250,400$ and 500 $\mathrm{ml} / \mathrm{min}$ ) respectively. The hydrogenated 
water having nitrate concentration varied from 115 to $284 \mathrm{mg} / \mathrm{l}$ were used for the study.

\section{Effect of temperature in denitrification}

Nitrate-N concentration was noted at temperatures ranging from 10 to $30^{\circ} \mathrm{C}$ at $2^{\circ} \mathrm{C}$ intervals for flow rates of 50,100, 150, 250, $400 \& 500 \mathrm{ml} / \mathrm{min}$. Significant impacts on denitrification process were observed above temperatures $16^{\circ} \mathrm{C}$. The influent and effluent nitrate- $\mathrm{N}$ concentration in reactor for various flow rates at different temperatures are presented in Figure 3. The nitrate-N removal in the reactor was observed 55.5 to $76.9 \%$, 38.1 to $69.9 \%, 38.1$ to $59.3 \%, 29.5$ to $52.3 \%$, 29.5 to $47.0 \%$ and 12.1 to $34.7 \%$ were observed in nitrification reactor at the filtration rates of $50,100,150,250,400 \&$ $500 \mathrm{ml} / \mathrm{min}$.

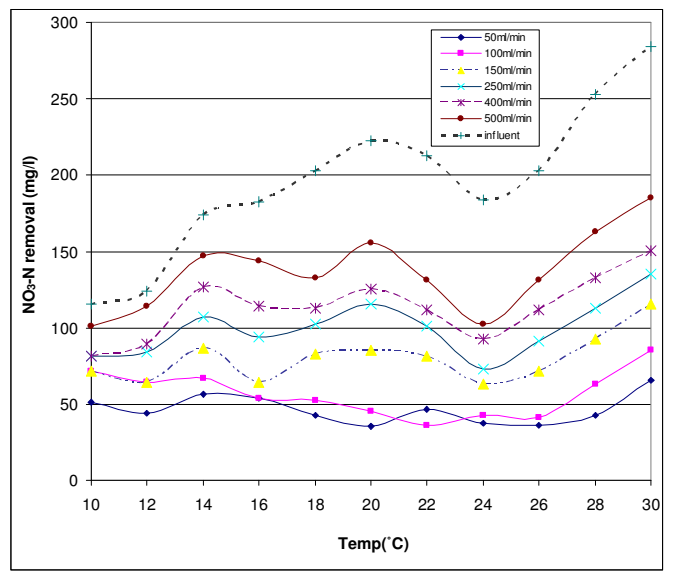

Figure 3. $\mathrm{NO}_{3}-\mathrm{N}$ removal in denitrification at various flows

At $10^{\circ} \mathrm{C}$, the ammonia- $\mathrm{N}$ removal was observed as 3.50, 4.82, 7.23, 9.32, 14.92 and $7.69 \mathrm{gm} / \mathrm{m}^{3} \mathrm{~h}$ in the reactor at the filtration rates of $50,100,150,250,400 \& 500 \mathrm{ml} / \mathrm{min}$ respectively. The nitrate- $\mathrm{N}$ removals in the reactor are significantly higher above $16^{\circ} \mathrm{C}$ in comparisons to the removal rate at $10^{\circ} \mathrm{C}$ is presented in Figure 4.

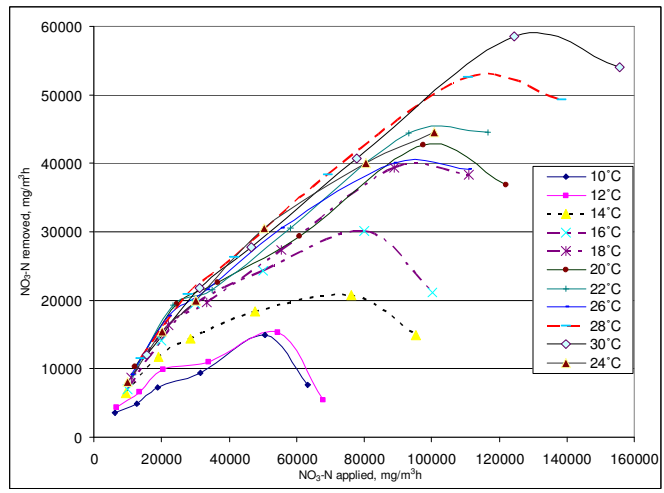

Figure 4. Denitrification rate $\mathrm{Vs} \mathrm{NO}_{3}-\mathrm{N}$ loading at various temperatures.

\section{CONCLUSION}

It can be deduced from the study that the temperature have a strong direct impact on the denitrification process. Denitrification was found more sensitive above $16^{\circ} \mathrm{C}$ temperature. The nitrate removal efficiency of $76.9 \%$ in the reactor packed with OBBs media at $30^{\circ} \mathrm{C}$ due to biological denitrification respectively. As the temperature increased, nitrate nitrogen removal was found higher in the biological denitrification process.

\section{ACKNOWLEDGEMENT}

The authors are grateful to the Centre for Research and Development (CARD), IOE, TU, Nepal and Norwegian University of Science and Technology (NTNU), Norway for providing the part of the financial support necessary for this study. 


\section{REFERENCES}

[1] Focht D.D. and Verstraete W. Biochemical ecology of nitrification and denitrification. Adv. Microbial. Ecol. 1977, 135-214.

[2] Lavania Amit, 2003, MSc. Thesis on "Zero- Valent Iron Assisted Autotrophic, Denitrification: Optimal Reactive Media Composition and Buffering”, IIT, Kanpur, pp. 16.
[3] Rittmann, B.E., McCarty, P.L., Substrate flux into biofilm of any thickness. J. Environ. Eng. 107, 1981, 889-897.

[4] WHO, 2004, "Guidelines for drinkingwater quality", third edition, pp 191,213 304.

[5] Biswas Susham, 2002, MSc. Thesis on "Zero- Valent Iron, $\mathrm{Fe}(0)$ Assisted Autotrophic, Denitrification", IIT, Kanpur, pp. 15. 
